\title{
Clara Immerwahr: A Life in the Shadow of Fritz Haber
}

\author{
Bretislav Friedrich and Dieter Hoffmann
}

\begin{abstract}
We examine the life of Clara Haber, nee Immerwahr (1870-1915), including her tragic suicide and its possible relation to the involvement of her husband, Fritz Haber, in chemical warfare. Clara earned a doctorate in chemistry from the University of Breslau, in 1900, as the first woman ever, and married the physical chemist Fritz Haber within a year of her graduation. With no employment available for female scientists, Clara freelanced as an instructor in the continued education of women, mainly housewives, while struggling not to become a housewife herself. Her duties as the designated head of a posh household hardly brought fulfillment to her life. The outbreak of WWI further exacerbated the situation, as Fritz Haber applied himself in extraordinary ways to aid the German war effort, which included his initiative to develop chemical weapons. The night that he celebrated the "success" of the first chlorine cloud attack and his promotion to the rank of captain, Clara committed suicide. However, we found little evidence to support express claims that Clara was an outspoken pacifist who took her life because of her disapproval of her husband's engagement in chemical warfare. We examine the origin of this "myth of Clara Immerwahr" that took root in the 1990s from the perspective offered by the available scholarly sources, including those that have only recently come to light.
\end{abstract}

\section{Prolog}

On April 23, 1909, Clara Haber wrote to her $\mathrm{PhD}$ adviser and confidant, Richard Abegg, the following lines:

\section{B. Friedrich $(\square)$}

Fritz Haber Institute of the Max Planck Society, Faradayweg 4-6, 14195 Berlin, Germany e-mail: brich@fhi-berlin.mpg.de

D. Hoffmann

Max Planck Institute for the History of Science, Boltzmannstraße 22, 14195 Berlin, Germany e-mail: dh@mpiwg-berlin.mpg.de

B. Friedrich et al. (eds.), One Hundred Years of Chemical Warfare: Research,

Deployment, Consequences, DOI 10.1007/978-3-319-51664-6_4 
What Fritz [Haber] has gained during these last eight years, I have lost, and what's left of me, fills me with the deepest dissatisfaction (Haber 1909).

This sobering summary of an eight-year marriage with Fritz Haber may serve as a key document about Clara's life and fate, not least in regard to her suicide six years later. Over the last twenty five years, Clara's suicide has been widely regarded not only as a personal tragedy and a result of a marital drama but, especially after the publication of her biography by Gerit von Leitner (Leitner 1993), as a consequence of Fritz Haber's involvement in chemical warfare in general and the first chlorine cloud attack at Ypres on 22 April 1915 in particular. More than that, it has been seen as a signal of a "feminine, life-preserving science" that opposes a patriarchal science, keen on securing power and on the exploitation of natural resources. Herein, we show that, based on the available biographical materials about Clara Haber, nee Immerwahr, this interpretation of her suicide is lopsided, lacking proper consideration of the complexity of Clara's personality and the circumstances of her life and time.

\section{Clara Immerwahr's Background}

Clara Immerwahr ${ }^{1}$ was born on 21 June 1870 at the estate of Polkendorf near Breslau, where her father, a PhD chemist, withdrew after the failure of his chemical start-up company. Apart from becoming a highly successful agronomist in Polkendorf and its surroundings, he co-owned a flourishing specialty store in Breslau dealing in luxury fabrics and carpets. The family maintained an apartment in Breslau where the Immerwahrs would stay during their frequent visits to the city. And Clara would live there during her studies in Breslau.

Breslau, characterized by Goethe as a "noisy, dirty and stinking" town (Goethe 1949, 378), transformed itself during the second half of the nineteenth century into a prosperous metropolis teeming with business and industrial enterprise. This was accompanied by an enormous increase in population, which doubled during the 30 years since 1875, reaching 471,000 in 1905 (Rahden 2008, 32). At the same time, Breslau developed into a major center of science and culture with a large educated middle class. There was the Schlesische Friedrich-Wilhelms-Universität, founded in 1811 (whose forerunner was the Leopoldina, founded in 1702), a number of colleges, as well as an opera house, several orchestras, and a city theater -all of them of national significance (Davies and Moorhouse 2002).

The era of economic and cultural prosperity that the city enjoyed coincided with the childhood and youth of Clara Immerwahr, whose family belonged to Breslau's well-to-do Jewish middle class. After Berlin and Frankfurt, the Jewish community of Breslau was the third largest, at over twenty thousand Jewish residents (Rahden

\footnotetext{
${ }^{1}$ Herein, we draw on the biography of Clara Immerwahr as detailed in Szöllösi-Janze (1998, 124131).
} 
2008, 32), and its synagogue, consecrated in 1872, even the second largest in Germany (Scheuermann 1994). Breslau's Jewish community was academically oriented and represented the city's "intellectual aristocracy," to which also the Immerwahrs belonged (Noack 1959). However, they were assimilated Jews, who participated in communal cultural life but would only rarely, if at all, go to the Synagogue. Jewish religion, customs and practices played essentially no role in the family life. The political attitudes of the Immerwahr family were liberal, which however entailed the cultivation and demonstration of a certain degree of Prussian-German national awareness and patriotism, especially after the German unification of 1871 (Clark 2007). Prussian was also the simple lifestyle of the family, which was frugal - not because of need but out of principle. So despite the family's wealth, Clara and her three siblings were brought up in modesty.

Apart from the virtues of simplicity, frugality and modesty, a great value was attached to education — not just for the son and heir, but also for the three daughters. This was typical for the German Jewish middle class, as $40 \%$ of female students at the higher schools in Breslau were Jewish. As opposed to Switzerland or the Anglo-Saxon countries, German high schools (Gymnasium) were out of limits for women until the beginning of the twentieth century. The Grand-Duchy of Baden was the first state in Germany to institute, in 1900, admission of female students to universities. Before then, it was only possible for women to attend university by a special permission or as guest auditors (Johnson 1998).

Clara's path to education was shaped by these constraints. She started her studies at a Höhere Töchterschule (sometime translated as "women's college") in Breslau, which was supplemented during the summer months spent at the Polkendorf estate by instruction provided by a private tutor. Clara graduated from the Töchterschule in 1892 at age 22. The school was supposed to provide a basic education for young women that was compatible with their social status and to prepare them for their "natural purpose," that is, as companions of their husbands, as housewives, and as mothers. Nevertheless, Clara was up for more and after graduating from the Töchterschule she entered a teachers' seminary, which was the only type of institution that offered a higher professional education to women (Szöllösi-Janze 1998, 124). However, the graduates of the teachers' seminary only qualified to teach at girls' schools and remained ineligible to enter university and study, for example, science, which is what Clara wanted to do. So in order to qualify for the university, Clara had to take intensive private lessons and pass an exam equivalent to the Abitur. This exam was administered by a special committee set up at a Realgymnasium in Breslau and Clara passed it successfully at Easter 1896, when she was 26 years old.

Subsequently, Clara began her studies at the University of Breslau, however only as a guest auditor, since in Prussia women would only become legally admissible as university students as late as 1908. Prior to this, starting in 1895, women were only allowed to attend lectures as guests, and even that was contingent upon the support of the professor and faculty and permission from the Ministry; the last required a certificate of good conduct, character references, and so on. It is difficult today to imagine what it meant to women to break into the male domain of 
higher learning and what kind of discrimination and humiliation was connected with it. Talk of "intellectual Amazons" was not uncommon.

The attitude of Max Planck, who accepted Lise Meitner as an assistant in 1912 and was helpful in promoting her career even earlier, declared in 1895, in response to a poll, that

Nature herself prescribed a role for women as mothers and housewives (Planck 1897, 256).

Thus according to the spirit of the time, Clara Immerwahr, with her wish to become a chemist, violated a law of nature. After her successful Abitur exam, Clara applied to the university curator's office for permission to attend lectures in experimental physics as a guest. And she had to proceed in a similarly awkward manner with all the other lecture courses that she wished to take.

From early on, Clara developed a keen interest in the then new field of physical chemistry. $^{2}$ Richard Abegg, one of this new field's pioneers and a friend of Fritz Haber's, played a key role in fostering Clara's interest in physical chemistry while paying little heed to Clara's guest auditor status. It was also Abegg who supervised Clara's PhD thesis - a part of the graduation requirement in chemistry - and who wrote a joint paper with Clara in 1899. The joint paper, published in 1900 (see next section and references therein), must have been perceived by the young female chemist as proof of her success and as an accolade. The following year, Clara submitted her dissertation and applied to be admitted to the Rigorosum final, which entailed exams in chemistry, physics, mineralogy, and philosophy. She passed the exams during the Fall and defended her thesis at the university's main auditorium on December 22, 1900.

Clara graduated with magna cum laude and her graduation was mentioned in the daily press, as Clara was the first woman on whom the University of Breslau conferred a doctoral degree. The left panel of Fig. 1 shows her photo during her university studies.

Richard Abegg (Fig. 2) assumed in 1899 an academic position at the Chemistry Institute of the University of Breslau, which belonged to the most prestigious in Germany. In 1909 Abegg became Ordinarius at the newly founded Technical University in Breslau. However, he would not live long enough to see through the construction of the new laboratory for physical chemistry at the Technical University, which was slated to be his own (Nernst 1913). Abegg was an early fan of balloon flying - and founded and presided over the Breslau ballooning club. He died in a ballooning accident in 1910 at the age of 41. As Nernst colorfully narrated in his obituary notice (Nernst 1913), Abegg was extremely hard working,

\footnotetext{
${ }^{2}$ Let us note that physical chemistry came about with a purpose, namely to save chemistry from taxonomy - from becoming a collection of little disconnected facts bred mainly by organic chemists. Its founders shared the view that chemistry should seek the general rather than cherish the particular and that the way to achieve it was to adopt the methods of mathematics and physics, Friedrich (2016). The success of physical chemistry in providing a common ground for chemistry was celebrated by Ostwald in his proclamation that "[p]hysical chemistry is not just a branch on but the blossom of the tree of knowledge" Ostwald (1887).
} 

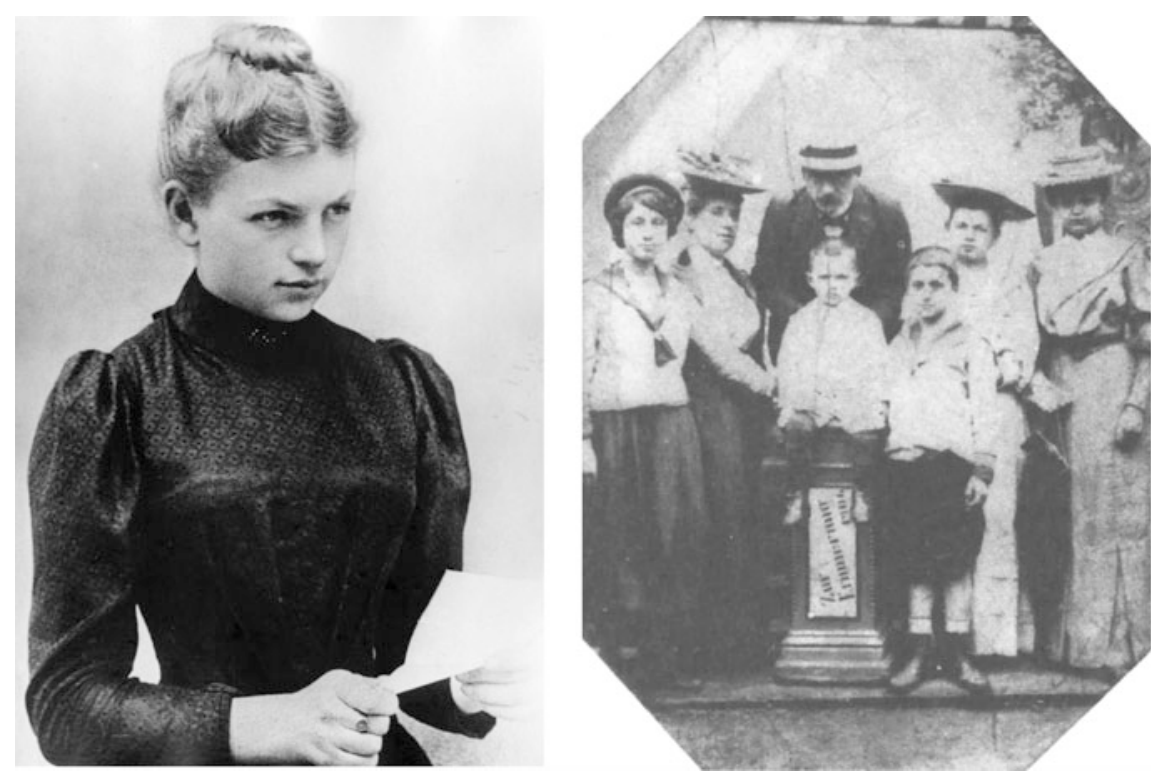

Fig. 1 Left panel Clara Immerwahr during her studies at the University of Breslau. Right panel Clara Haber, nee Immerwahr (2nd from right), on a family photo from 1906 with her son Hermann (seated in the center), her husband Fritz Haber (standing behind Hermann) and the landlady (2nd from left) of Habers' Karlsruhe apartment with her children; on the right is Habers' maid servant. Photos: Archiv der Max-Planck-Gesellschaft, Berlin-Dahlem

yet always had time for everybody. That must have surely made him an ideal academic teacher and adviser, particularly for Clara.

Otto Sackur (Fig. 2) was Clara's ten year junior Kommilitone, who studied chemistry at the University of Breslau, where, like Clara, he found an enlightened mentor in Richard Abegg. Sackur served on Clara's PhD committee as a referee.

As a Privatdozent at the University of Breslau, he was left after Abegg's death without an academic patron or a laboratory. It was during this period that Sackur launched his research at the intersection of thermodynamics and quantum theory. A reward in the form of a more senior appointment came at the end of 1913 when, thanks in part to mediation by Clara Haber, Sackur received a call to Haber's Kaiser-Wilhelm-Institut in Berlin. In 1914 he was promoted to the rank of a department head. After the outbreak of WWI he was enlisted in military research at Haber's institute, but continued on the side his experiments on the behavior of gases at low temperatures. In December of 1914, he was killed in a laboratory accident at his work bench, while trying to tame cacodyl chloride for use as an irritant and propellant (Badino and Friedrich 2013). He was just 34 years old.

While Abegg represented Clara's connection to science who, in addition, acted as her "cheerleader" and confidant in private matters, Otto Sackur was Clara's friend and Kommilitone. After Sackur's laboratory accident, Clara was among the first to attend to the injured. She proved capable of acting rationally in a situation 

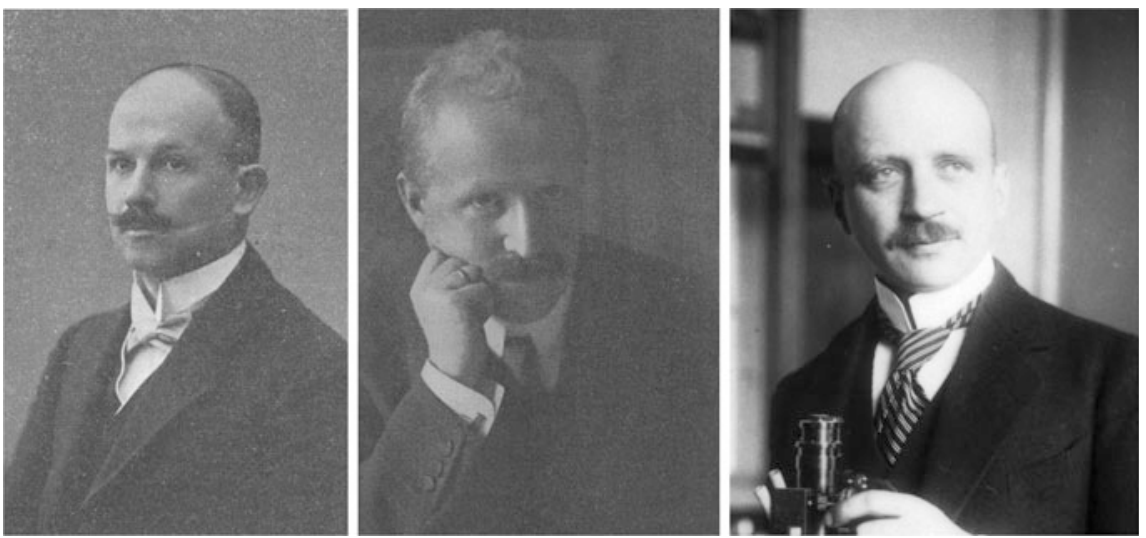

Fig. 2 Left panel Richard Abegg (*1869 Danzig; $† 1910$ Tessin). Abegg graduated in chemistry from the Berlin University (1891) under August von Hofmann, received his Habilitation (1894) under Walther Nernst, was Extraordinarius at the University of Breslau (1899-1909), Ordinarius at the Technische Hochschule Breslau (1909), member of the Leopoldina (1900) and editor of the Zeitschrift für Elektrochemie (1901). Photo: Arrhenius, 1910. Central panel Otto Sackur $(* 1880$ Breslau; $† 1914$ Berlin). Sackur graduated in chemistry from the University of Breslau (1901) under Richard Abegg, received his Habilitation (1905) under Abegg, was department head at the Kaiser Wilhelm Institute for Physical Chemistry and Electrochemistry (1914). Photo: Jahresbericht der Schlesischen Gesellschaft für Vaterländische Kultur 1915, 1: 35-37. Right panel Fritz Haber (*1868 Breslau; $\uparrow 1934$ Basel). Haber graduated in chemistry from the Berlin University (1891) under August von Hofmann, received his Habilitation (1894) under Hans Bunte, was Extraordinarius (1898) and Ordinarius (1906) at the Technische Hochschule Karlsruhe, founding Director of the KWI für Physikalische Chemie und Elektrochemie (1911-1933), Honorarprofessor (1912-1920) and Ordinarius (1920-1933) at the Berlin University, Member of the Prussian Academy (1914). He was awarded the Nobel Prize in Chemistry for 1918. Photo: Archiv der Max-Planck-Gesellschaft, Berlin-Dahlem

drastic to the extreme and to coordinate attempts to help the injured. However, Sackur died on the spot, before her eyes; Clara was crushed by Sackur's death. At the site of accident, Fritz Haber was just gasping for air in the arms of a coworker. He was shattered to the point that he stopped for good explosives research at his institute (James et al. 2011, 27).

\section{The Scientific Work of Clara Immerwahr}

Clara's scientific record consists of three research papers (Immerwahr and Abegg 1900; Immerwahr 1900a, 1901a), a supplement (Immerwahr 1900b) and an erratum (Immerwahr 1901b) to one of the research papers. Her first research paper is co-authored by her PhD adviser, Richard Abegg, the other two are solo. The second solo paper is an excerpt from Clara's $\mathrm{PhD}$ thesis. Clara's work concerned solution chemistry, one of the main preoccupations of physical chemistry at the time, and 
revolved about the connections among the conductivity, solubility, degree of dissociation, electrochemical potential and what was called electro-affinity.

The paper with Abegg, which expanded on the ideas of the 1899 Abegg-Bodländer paper that introduced the notion of electro-affinity as an organizing principle in chemistry (Abegg and Bodländer 1899), pretty much determined the topic and methodology of Clara's thesis paper. The thesis paper dealt in a more systematic way with the interplay between solubility of choice heavy metal salts and the electro-affinities of the constituent groups and atoms. Apart from providing tables of experimentally determined values of quantities such as equilibrium concentrations and relative electrode potentials, the paper aimed at assessing the issue of whether electro-affinities were additive quantities. The latter might be the reason for the relatively high number of citations (24) this paper has so far received. ${ }^{3}$ However, one should keep in mind that quite a few of the publications citing Clara's paper are recent biographical articles about Clara rather than scientific papers.

Clara's second paper aimed to expand the solubility data base to include copper salts, using the ideas and methods developed by Walther Nernst, Wilhelm Ostwald and Friedrich Wilhelm Küster. The last was Clara's professor at the University of Breslau, who also deserves credit for arousing her interest in physical chemistry. He moved to the Bergakademie in Clausthal in 1899 and it was in Küster's Clausthal laboratory that Clara undertook the measurements reported in her second paper. As she noted, her data could be regarded as a corroboration of the Nernst-Ostwald-Küster theory.

Clara's PhD adviser Richard Abegg became well known for his work on valence that led to the octet rule. Clara's work on electro-affinity was somewhat related to this line of Abegg's research, but her contribution was not deemed significant enough to warrant Clara's inclusion in Svante Arrhenius's list of half a dozen or so of Abegg's former affiliates who had contributed to Abegg's research the most (Arrhenius 1910). To be sure, Sackur was not on that list either. However, Sackur made a name for himself in a research area that lay outside of Abegg's range of interests and published his key work only after Abegg's death (Badino and Friedrich 2013). It should also be noted that Clara's work, unlike Abegg's or Sackur's, did not seek to enrich the conceptual framework of physical chemistry in any way or to launch a new research direction.

Apart from her work as a researcher, Clara also gave public lectures, both in Breslau and later in Karlsruhe, on the broad topic of science in the household. Inspired by Lassar Cohn's popular book Chemistry in daily life ${ }^{4}$ Clara's lectures attracted audiences of up to one hundred women (Szöllösi-Janze 1998, 194).

\footnotetext{
${ }^{3}$ As of 7 September 2016.

${ }^{4}$ The book was translated into many European languages. Its author would become professor of chemistry at the University of Königsberg.
} 


\section{Clara's Husband: Fritz Haber}

Apart from Abegg and Sackur, there was another pioneer of physical chemistry who entered Clara Immerwahr's life, namely Fritz Haber ${ }^{5}$ (Fig. 2). Likewise a native of Breslau, Fritz likely met Clara at a dancing class (Szöllösi-Janze 1998, 124f). Little is known about this liaison, but Haber would later admit, at the occasion of his engagement with Clara in April 1901, that he was "in love with [his bride] as a [high school] student" and that during the intervening years he had "honestly but unsuccessfully" tried to forget her (Haber 1901). When the freshly minted Dr. Immerwahr appeared in April 1901 at the annual conference of the German Electrochemical Society in Freiburg - as the only female scientist-the affair between her and Haber was quickly rekindled. ${ }^{6}$ As Haber would put it later in one of his letters (cf. Szöllösi-Janze 1998, 735, fn. 165), "we saw each other, we spoke and in the end Clara let herself be persuaded to give it a try with me." Clara would describe her motives for her acceptance of Fritz's advances in the already mentioned 1909 letter to her confidant Abegg:

It has been my approach to life that it was only then worth living if one developed all one's abilities to the utmost and lived through everything that a human life can offer. And so I finally settled upon the idea of marriage [...] under the impulse that if I did not marry a decisive page in the book of my life and a string of my soul would lie idle. But the boost that I got from it was very short (Haber 1909).

As Margit Szöllösi-Janze, the biographer of both Fritz and Clara Haber, pointed out, their wedding, which took place already on August 3,1901, marked the end of "the chapter 'chemical science' in Clara's book of life" which "must have been clear to the chemist" even without "any effects on the string of her soul" (Szöllösi-Janze 1998, 129).

Upon looking at the last decade of Clara's life, one has to agree. Although at the beginning she may have harbored the hope that she would be able to resume her scientific work at some point, she must have increasingly let go of such hopes as time went on. During the first years of her marriage, Clara appeared at lectures as well as in the laboratories of the Technische Hochschule in Karlsruhe, where her husband would soon become the founding director of its institute for physical chemistry and electrochemistry.

Moreover, it seems that at the time Fritz Haber would involve his wife in his research and share with her his scientific ideas, as suggested by the dedication of his 1905 classic textbook Thermodynamics of technical gas-reactions:

To my dear wife Clara Haber, Ph.D., in gratitude for her silent co-operation (Haber 1908).

\footnotetext{
${ }^{5}$ Fritz Haber's authoritative biographies have been written by Szöllösi-Janze (1998) and Stoltzenberg (2004).

${ }^{6}$ In fact Haber asked Abegg to take Clara along to the Freiburg conference.
} 
However, Clara was apparently not involved in doing any calculations for the book, as implied by the fact that this task fell to others (Haber 1908, x).

Nevertheless, that Clara's involvement in Haber's research entailed more than a silent co-operation transpires in her correspondence with Abegg, in which she reports about Haber's progress in writing the textbook, discusses academic appointments, and solicits advice about her own public talks. However, the dream of an equitable and reciprocal scientific marriage — such as that of Pierre and Marie Curie in Paris - did not come true.

The turning point likely occurred when their son Hermann was born in $1902^{7}$ and/or when Haber became Ordinarius at Karlsruhe in 1906. Hermann was a sickly child, who claimed a lot of his mother's attention. Clara cared for the son lovingly while at the same time running a demanding household. At the beginning, the young family could not afford service staff and so Clara had to do a lot by herself. In a letter to Abegg written in 1901 from Karlsruhe, Clara declared that she would get back to the laboratory

... once we become millionaires and will be able to afford servants. Because I cannot even think about giving up my [scientific work] (Haber 1901).

As we know, the Habers did get rich, ${ }^{8}$ but nevertheless Clara would never return to the laboratory, despite Haber's positions as Ordinarius at Karlsruhe and later director of a Kaiser Wilhelm Institute. As the years went by, she would fall increasingly into the traditional role of a representative professorial wife, a housewife preoccupied with the well being of the family and a caring mother. This was aggravated by Haber's sharp-elbow mentality and his obsession with his work and career, which left little room for Clara's professional development and reduced her more and more to a mother/housewife. Clara broke down as a result and, as Szöllösi-Janze put it:

the heyday that Haber had lived through in Karlsruhe was for his wife Clara her intellectual twilight (Szöllösi-Janze 1998, 353).

Clara saw it herself and committed her feelings to paper in her above mentioned letter to Abegg from 23 April 1909 where she said that

[Fritz is a type of person] on the side of whom every other person who does not force his way even more recklessly at the other's expense than him, will perish. And that is the case with me (Haber 1909).

There were still six years left until Clara's voluntary exit from life on May 2, 1915. During this time Fritz Haber would enjoy further scientific and social ascent: in 1909, he laid the scientific foundations for the catalytic synthesis of ammonia from its elements ("bread from air") and in 1911 he became the founding director of the Kaiser Wilhelm Institute for Physical Chemistry and Electrochemistry in Berlin.

\footnotetext{
${ }^{7}$ This appears similar to the crisis of the marriage between Albert Einstein and Mileva Maric.

${ }^{8}$ Fritz Haber was awarded the patent rights for the ammonia synthesis in 1910, Szöllösi-Janze (1998).
} 
Thereby Haber reached not only the Olympus of science in Germany but of science full stop. Clara could partake in the glory of it all-however not as a scientist but rather as a spouse of a scientist, a difference that the sensitive and earnest Clara surely must have reflected upon. The growing alienation of the couple was obvious to their contemporaries for whom

the wearing down and the difficulties between the spouses were not of a petty kind but rather fundamental (Noack 1959, 301).

The strains and conflicts between Clara and Fritz further aggravated after the outbreak of WWI. In keeping with the maxim "In peace for mankind, in war for the fatherland," Fritz Haber applied himself in extraordinary ways to aid the German war effort (Stern 2011; Dunikowska and Turko 2011; Friedrich and James, this volume).

In part encouraged by the French use of tear gas (Haber 1924) - including its lethal variants-Haber took the initiative to employ chemistry in resolving the greatest strategic challenge of the war, namely the stalemate of trench warfare. Brought to glistening prominence by Germany's need to produce "gunpowder from air," Haber, backed by the profiteering chemical industry, was able to persuade his country's military leadership to stage a battlefield test of a chemical weapon-of "poison instead of air." This would earn him the epithet "father of chemical warfare."

The lethality of the April 22, 1915 chlorine cloud attack at Ypres lured the German military into adopting chemical warfare. Haber was promoted, by an imperial decree, to the rank of captain.

Haber celebrated the "success" at Ypres and his promotion at a gathering in his directorial mansion in Dahlem. The gathering took place in the evening of May 1, 1915. Afterwards, during the night from May 1 to May 2, Clara Haber committed suicide. She shot herself, with Haber's army pistol, in the garden of their mansion. Apparently, Haber, sedated by his daily allowance of sleeping pills, didn't hear the shots (there were two). Clara was found dying by their thirteen-year-old son Hermann.

\section{Clara Haber's Suicide}

Most of the materials related to Clara's suicide were generated nearly four decades later via interviews for the so-called Jaenicke Collection, named after Johannes Jaenicke (Hahn 1999), a Haber collaborator who planned to write Haber's biography and who headed the forerunner of the Archive of the Max Planck Society (Henning 1990). Mentions made in memoirs and personal correspondence of

\footnotetext{
${ }^{9}$ Usually quoted in this abbreviated form. For a full quote in German, cf. Haber (1920). Haber was referring to the attitude of Archimedes.
} 
people who knew the Habers provide additional tidbits, albeit sometimes only between the lines. The coincidence of the suicide with the chlorine cloud attack at Ypres and Fritz Haber's key role in it gave rise to speculation and there were-as noted by Jaenicke - "numerous contradictory versions in circulation" (Jaenicke 1958). The Haber family treated the tragic event with utmost discretion, as a result of which there are no primary sources available, such as farewell letters, that would clarify the motive. Likewise, there are essentially no authentic contemporary testimonials available that shed light on the tragic event. Almost all of the extant testimonials are from the 1950s and 1960s, solicited and gathered by Johannes Jaenicke for his collection. ${ }^{10}$ Twenty years earlier, in early 1940s America, Morris Goran, about whom little is known, except that he held a position at Roosevelt College in Chicago at some point, attempted to interview German émigré scientists about the German scientific establishment in general and about Fritz Haber in particular, however, with a mixed success. For instance James Franck, upon being contacted by Goran, characterized him as "the terrible guy in America [Goran], who wants to prove what a [great] man he is by writing about Fritz Haber" (Jaenicke 1958). In 1947, Goran published a rather hagiographic article about Fritz Haber (Goran 1947) and in 1967 a book The Story of Fritz Haber (Goran 1967), which contains a brief passage about Clara's suicide. In the passage, Goran stated that Clara was "vitally affected" (Goran 1967, 71) by her husband's involvement in WWI chemical warfare and committed suicide after a heated argument with Fritz about what she considered to be "a perversion of science" and "a sign of barbarism" (Goran 1967, 71). Goran gives no evidence or sources for either this scenario or these statements. Apparently, the much-quoted phrase about the perversion of science and barbarism, ascribed to Clara, is Goran's own. Apart from his political and moral categorization of Clara's suicide, Goran also points out for the first time that Clara was depressive and that

chemical warfare was an avenue or excuse for the morbid worry she seemed to favor (Goran 1967, 71).

However, Goran doesn't give any references here either, which led Margit Szöllösi-Janze to the characterization of his book as one where "the line between a historically correct study and fiction is blurred" (Szöllösi-Janze 1998, 395).

In her Haber biography, Szöllösi-Janze has already critically evaluated the sources about Clara and her suicide that can be found in the Jaenicke Collection (Szöllösi-Janze 1998, 393-399), with the conclusion that the motives for Clara's suicide are as unclear as the available sources are ambiguous - and rare. However, the possible motives can be divided into two groups, listed on the left and right side of Table 1: on the left are sources suggesting that Clara's suicide had to do with Fritz Haber's engagement in the German war effort/chemical warfare and on the right with her unfulfilling personal (and absent professional) life and with depression.

\footnotetext{
${ }^{10}$ The individual items of the Jaenicke Collection have never been published.
} 
Table 1 Possible motives for Clara Haber's suicide. Left: Sources suggesting that the motive had to do with disagreements about Haber's involvement in the German war effort. Right: Sources suggesting that Clara's suicide had to do with disagreements about personal matters and/or her depression

\begin{tabular}{|c|c|}
\hline $\begin{array}{l}\text { Disagreements about Fritz Haber's } \\
\text { involvement in German war effort }\end{array}$ & $\begin{array}{l}\text { Disagreements about personal } \\
\text { matters; depression }\end{array}$ \\
\hline Hans Krassa (1957); Archiv MPG ${ }^{\mathrm{a}}$ & Haber (1909); letter to $\mathrm{Abegg}^{\mathrm{c}}$ \\
\hline Franck (1958); Archiv MPG ${ }^{\mathrm{b}}$ & Haber (1915); letter to Tamaru ${ }^{\mathrm{d}}$ \\
\hline Goran (1967); source not given & Hahn (1915); letter to Otto Hahn ${ }^{\mathrm{e}}$ \\
\hline Mendelssohn (1973); source not given & Meitner (1915); letter to Edith Hahn ${ }^{\mathrm{e}}$ \\
\hline \multirow{6}{*}{$\begin{array}{l}\text { Von Leitner (1993); sources: either } \\
\text { not given or Goran, Lütge, Lummitzsch } \\
\text { tapped selectively }\end{array}$} & Lummitzsch (1955); Memoirs $^{\mathrm{f}}$ \\
\hline & Noack (1959); Archiv MPG \\
\hline & Goran (1967); source not given \\
\hline & Lütge (1958); Archiv MPG \\
\hline & Haber (1970); Memoirs ${ }^{\mathrm{i}}$ \\
\hline & $\begin{array}{l}\text { Ebbinghaus (1993); review of von } \\
\text { Leitner's book }^{\mathrm{j}}\end{array}$ \\
\hline
\end{tabular}

${ }^{a}$ Krassa (1957)

baenicke (1958)

${ }^{c}$ Haber (1909)

${ }^{\mathrm{d} C l a r a}(1915)$

${ }^{\mathrm{e}}$ Meitner (1915)

${ }^{\mathrm{f}}$ Lummitzsch (1955)

${ }^{\mathrm{g}}$ Noack (1959)

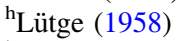

${ }^{\mathrm{i}}$ Charlotte (1970)

${ }^{\mathrm{j}}$ Ebbinghaus (1993)

Hermann Lütge, the former fine-mechanic at Haber's institute, ${ }^{11}$ when asked by Jaenicke whether Clara committed suicide in response to "Haber's involvement in the abhorrent gas warfare" and whether Clara's "ethical asperity was a consequence of a hereditary depressive disposition," stated the following:

No, this is not to be presumed. Frau Geheimrat [Clara] ... was not in a state of mind to contemplate the abhorrence of chemical warfare ... Yes, sometimes was Frau Haber gloomy, especially after being harshly rebuffed for mothering her husband too much (Lütge 1958, 260).

A similar answer was given to Jaenicke by Adelheid Noack, the niece of Clara's brother-in-law:

\footnotetext{
${ }^{11}$ Clara was the godmother of Hermann Lütge's son (private communication, Michael Lütge, 2016).
} 
There are various more or less pathetic accounts of her [Clara's] suicide, for instance that she had beseeched him [Fritz Haber] to abandon chemical warfare. These accounts are a nonsense (Noack 1959).

This is contrasted by James Franck's opinion, who stated in his conversation with Jaenicke that Clara was

a good, talented person with distinct views, which often contradicted those of her husband ... she wanted to reform the world. That her husband was involved in chemical warfare had surely an effect in her suicide (Jaenicke 1958, 1449).

\section{However, Franck added that Fritz Haber}

expended an immense effort to reconcile his and [Clara's] political and human views.

Another proponent of the view expressed by James Franck was the physical chemist Kurt Mendelssohn, who had worked before his emigration in 1933 in both Berlin and Breslau. ${ }^{12}$ In his book The World of Walther Nernst he stated:

... there was a macabre sequel to his [Fritz Haber's] decision to develop poison gas. His wife, Dr. Clara Immerwahr, who was also a chemist, had pleaded with him [Fritz Haber] again and again not to work on gas warfare. His answer was that his first duty was to his country and that no argument, not even the entreaties of his wife, could shake his resolve. On the evening of Haber's departure for the front, Clara committed suicide (Mendelssohn 1973, 83).

An additional testimonial about a possible role of chemical warfare in Clara's suicide was delivered by her cousin Hans Krassa, according to which Clara visited Krassa's wife shortly before the suicide to confide to her about the "gruesome effects" of chemical warfare that she had witnessed, in particular the "testing on animals" (Krassa 1957, 1470). Krassa, however, added that other factors may had been at play as well. As far as Clara's disposition was concerned, Krassa stated that "the word gloom goes too far" and that "one certainly cannot speak of a hereditary depression."

That Clara was "exceedingly nervous," especially in the last years of her life, can be found in the testimonial by Otto Lummitzsch, the adjutant of the commander of the gas troops, who witnessed a visit by Fritz and Clara Haber at the proving ground in Wahn near Köln. He characterized Clara as

a nervous lady, who was already then in sharp opposition to Geheimrat Haber's ventures to the Front along with the gas troops (Lummitzsch 1955).

This quote further attests to Clara's habit of "mothering" her husband.

Another aspect of Clara's personality transpires in the manner she behaved and dressed. According to James Franck,

[Haber] liked to represent, whereas [Clara] exaggerated the simplicity of her manner and she dressed poorly - [perhaps] as a protest? (When I visited [the Habers] for the first time, the door was answered by a person whom I held for a cleaning woman. And I thought that it

\footnotetext{
${ }^{12}$ It is conceivable that James Franck was in fact the source of Mendelsohn's account.
} 
would have been fitting if in such a fine household [as Habers'] the cleaning woman had dressed a little more nicely - but it was Frau Geheimrat [Clara] herself) (Franck 1958).

Out of the rest of the testimonials on the right of Table 1 we would like to bring to the fore additional tidbits provided by Adelheid Noack and by Hermann Lütge. In her conversation with Jaenicke, Noack also mentioned that Clara was "horrified by anything sensual," in keeping with the fact that she had quit the marital bedroom in 1902, never to return to it (Noack 1959). This fact as well as Noack's testimonial was corroborated by Haber's second wife, Charlotte Nathan, who had access to such intimate information more than anybody else (Haber 1970, 83 and 89). A real bombshell was dropped by Hermann Lütge, who testified that during the fateful night of May 1-2, 1915, Clara caught her husband in flagranti with Charlotte Nathan (Lütge 1958, 260). Charlotte worked as a manager of the then incipient club "Deutsche Gesellschaft 1914," where she and Haber got to know each other and was invited to the grand celebration of the "success" at Ypres in Habers" mansion (although Charlotte later contradicted it). The sociologist Angelika Ebbinghaus (Ebbinghaus 1993) as well as the historian Margit Szöllösi-Janze (Szöllösi-Janze 1998, 398) indicated that they tend to the view that Clara's discovery of her husband's affair may have been the actual trigger for her suicide.

Although provided by contemporaries, the above testimonials had been delivered with a delay of about 50 years, which makes them historiographically problematic. However, there are two recently surfaced documents that had been written within days of Clara's suicide and that answer some of the questions posed in connection with it: they are the letters (dated May 5, 1915) by Edith Hahn, the wife of the chemist Otto Hahn, to her husband and the letters (dated May 6 and 9, 1915) by Lise Meitner, Otto Hahn's collaborator and colleague at the Kaiser Wilhelm Institute for Chemistry, ${ }^{13}$ to Edith Hahn. These letters, recently published by Eckart Henning (Henning 2016), the former director of the Max Planck Archive, confirm that Clara was mentally unstable. So Edith Hahn wrote:

Of course was the woman [Clara] ill, she'd been always strange - everybody was mocking her (Hahn 1915).

\section{And Lise Meitner reports that}

as of late [Clara] had always made an impression of being agitated (Meitner 1915).

The letters also agree that the reasons for Clara's act of desperation were to be found in her private life. Edith Hahn wrote to her husband that

he [Fritz Haber] [was] guilty. I have the feeling that she was [strongly] attached to him and that he treated her badly - or at least quite indifferently, and that she suffered more than we can imagine. Recently, she complained [to me] that he would never write to her [from the front], this came out inadvertently and was so sad that I lied to her that you write to me only seldom [as well] and [pointed out to her] that her husband has had even less time [than you

\footnotetext{
${ }^{13}$ The KWI's for Chemistry and for Physical Chemistry and Electrochemistry were located next to each other-and the on-campus Haber mansion.
} 
did]. Poor, poor woman. I've had always the feeling that he was fed up with her, which I could understand to a certain extent (Hahn 1915).

In line with this, Lise Meitner wrote that

she [Clara] has recently made remarks to the effect that she was unhappy in her marriage. And that he [Fritz Haber] is not exactly an affectionate person. Anyway, it's a very sad story (Meitner 1915).

That the likely reasons for Clara's suicide were personal is supported by yet another contemporary document. At the turn of 1914/1915, an exchange of letters took place between Setsuro Tamaru, Haber's former Japanese collaborator, who had to leave Germany after the outbreak of the war, and Clara Haber. In his lengthy letter, written on Christmas Eve 1914, Tamaru complains about his personal situation as a guest in Theodore Richard's laboratory at Harvard, characterized by personal and scientific isolation; about being forced to leave Germany; and about receiving "not a single line whatsoever, no reply from Herrn Geheimrat [Fritz Haber]" (Tamaru 1914). Furthermore, Tamaru's six-page letter is concerned with the political and military situation during the first year of WWI and contains Tamaru's stance regarding war and peace:

I am a pacifist of sorts and am always against war. A war doesn't decide anything, just breeds the next war (Tamaru 1914).

In her equally lengthy reply, Clara in no way reacts to Tamaru's stance and describes the "melancholy of our separation" and "your [Tamaru] being missed at the Christmas table" instead (Haber 1915). The silence of Fritz Haber and of others at the institute Clara explains by pointing out that

... my husband is working 18-hour days, almost always in Berlin, I'm taking care of 57 poor children ${ }^{14}$ and Hermann [the son] has been ill since November ... Apart from that we are all adversely affected by the outrage and the dull pressure [of the war] that disable any impulse to do anything else than to help the country in the few remaining hours [of the day] (Haber 1915).

Clara also provides a brief report about Otto Sackur's "terrible accident" and the shock she suffered as a result and concludes by stating:

To your political contentions, which were very interesting for us [to read], I will not respond; I am too ignorant in the matters of foreign affairs to be able to properly answer [your points]. You are certainly right in many respects, but have somewhat one-sided views on some points (Haber 1915).

Even if one takes into account that at the time international correspondence was subject to censorship, what transpires in Clara's letter is a woman made heavy-hearted by human suffering and the burdens of the war rather than a political activist or indeed a pacifist. This makes quite questionable the image of Clara, created in the 1990s - see below-according to which she was an outspoken

\footnotetext{
${ }^{14}$ Clara ran a makeshift kindergarten that made use of the premises of Haber's KWI. The fathers of the " 57 poor children" were on the front and their mothers had to work in order to make ends meet.
} 
pacifist. Likewise questionable is Clara's opposition to her husband's involvement in chemical warfare and thus the subsumed motive of her suicide as having been connected with it. So Dr. Kremmer, the principal of Hermann Haber's school, described in his condolence letter to Hermann upon the death of Fritz Haber how Hermann's "Frau Mutter" came to him

to report on the success of the first gas attack at Ypres right after receiving a telegram from the front about it (Kremmer 1934).

And Hermann Lütge, in his testimonial, stated that

the boss [Clara] was proud of the services provided by her husband (Lütge 1958).

Another controversy connected with Clara's suicide concerns Fritz Haber's behavior during the aftermath of the harrowing event. Haber's departure for the eastern Front the same day (May 2) was often portrayed as a reckless abandonment of his thirteen-year-old son Hermann and a sign of callousness and egotism. Even Szöllösi-Janze argues that the visibly shaken Haber may have regarded the Front as a place to which he could escape from the tragic reality at home. However, the above-quoted letter by Lise Meitner sheds new light on this aspect as well:

As you know, Haber was supposed to leave in the morning, but stayed until the evening, when he was [finally] forced to depart. I'm told that he inquired at the [military] headquarters whether, out of consideration for the unfortunate event, he could postpone his departure, but his request was denied (Meitner 1915).

Although Lise Meitner qualified her statement by adding "Whether it's true, I of course don't know," the passage nevertheless suggests that Haber was not as unfeeling a chemical warrior who left his son in the lurch without a reason as had been previously conjectured.

\section{The "Myth of Clara Immerwahr"}

The scarcity and ambiguity of the historical record notwithstanding, during the 1990s a narrative took root according to which Clara Haber was supposedly a pacifist and decisive opponent of chemical warfare, in contrast to her husband Fritz Haber, who was chemical warfare's main proponent and Clara's oppressor to boot. It appears that this narrative was catapulted into the public sphere in Germany and beyond by Gerit von Leitner's book Der Fall Clara Immerwahr. Leben für eine humane Wissenschaft, published in 1993 (second edition 1994) as well as various dramatizations derived from it. In it, Clara is presented as an outspoken pacifist (not unlike the Czech-Austrian 1905 Nobel Peace Prize laureate Bertha von Suttner) and a star scientist (not unlike Marie Curie) who was destroyed - as both a person and a scientist-by her oppressive and opportunistic husband. The sources in von Leitner's book are either not given or tapped selectively, so as to provide a spotless image of Clara while portraying Fritz Haber as a kind of Dr. Evil. Von Leitner's 
account ignores other sources that suggest that the reasons for Clara's suicide may have had to do with her private life. These testimonials or opinions are listed on the right in Table 1.

The emphasis on Clara's 1909 letter to Richard Abegg (Haber 1909) is a case in point. Written on funeral stationary and opening with a tirade about her inability to locate a fountain pen (described - in pencil - on two pages out of twelve), Clara denounces her husband and details her unfulfilling life with him. The letter may have been triggered by jealousy, after Abegg, during his visit to Karlsruhe, congratulated Fritz Haber on his discovery of the catalytic synthesis of ammonia without mentioning Clara (Ebbinghaus 1993). Clara, however, had not been involved in research-her own or Haber's - since about 1901, as she had acknowledged in the same letter. The letter is special in that it is the only one written by Clara to Abegg (or anybody else for that matter) where she had lost her nerve and complained about Haber and their marriage.

Von Leitner's book (Leitner 1993) apparently struck a chord with the Zeitgeist, as it had been well-in some cases even euphorically - received not only in feminist and pacifist circles but also by a majority of German literary critics writing for Germany's leading newspapers and magazines. So, for instance, Volker Ullrich published in Die Zeit a review where he paid tribute to von Leitner's book as

one of the best examples of a new, woman-inspired form of writing history, ... a fascinating historical portrait ... that reveals what was covered up and concealed for decades (Ullrich 1993).

Ullrich's review became emblematic for the reception of the book by other critics and its tenor can be found in many additional, roughly thirty reviews that we could identify, published in leading supra-regional newspapers such as Frankfurter Allgemeine Zeitung, Frankfurter Rundschau, Die Welt, Süddeutsche Zeitung, Die Tageszeitung, in regional periodicals such as Sächsische Zeitung, Tagesspiegel, Westfalen Blatt, Main Echo, Emsdettener Tageblatt, as well as in journals like Emma, 1999, Zeitschrift für Sozialgeschichte, or on ARD radio stations. And the New York Review of Books chipped in as well (Perutz 1996). Time and again, the reviews had made a connection to contemporary events in the 1990s, including misuse of scientific research by the military and the Gulf War 1990-1991. Another issue discussed in the reviews, one that touches upon the core of von Leitner's book, is that of equality in scientific/academic marriages such as that of the Habers and the fostering of academic careers of female scientists. All that lent relevance to von Leitner's book vis-à-vis the political trends and debates of the 1990s and made it into a vehicle for furthering the opinions, ideals and Wunschbilder of the peace movement, feminism and antimilitarism. Clara's attempt to have a self-determined life as a woman, mother and scientist as well as her tragic suicide are interpreted as a "[beacon of a] feminine, life-preserving science" and juxtaposed with the male, patriarchal power-oriented science concerned with the exploitation of resources. 
Volker Ullrich's review is a prime example of such an interpretation of von Leitner's book that had over time acquired an almost paradigmatic character. As apodictic appear Ullrich's statements according to which von Leitner tore down "the veil of falsified legend built [around Fritz Haber]." However, what had been overlooked is that, through the back door, another legend was being ushered in: the myth of Clara Immerwahr. According to this myth, Clara committed suicide in opposition to the gas warfare and as a desperate protest against the development of weapons of mass destruction by her husband, whose effort was contemptuous of human life. This interpretation is not only too monocausal and simplistic, but is difficult to support by the available historical sources, as already outlined above; in the best case, it can be viewed as a catchy hypothesis lacking supporting evidence. Incidentally, a criticism of this sort had been already leveled against von Leitner's book by several reviewers during the 1990s. For instance, the historian of science Ernst Peter Fischer writing in Die Tageszeitung (and also Weltwoche) denounced not only the stylistic and substantive shortcomings of the book, characterizing it as a "total failure [total misslungen]," but he also pointed out that because of the missing references it is unclear whether the book is a "reliable rendition [of historical facts]" and how one-sided its interpretations are (Fischer 1993a, b). A similar argument was presented in the review by the historian Jakob Vogel in the Frankfurter Allgemeine Zeitung, who noted that

a personal fate whose meaning comes about through a true-to-life contrariness [is sacrificed to] political correctness (Vogel 1993).

The main deficiency of von Leitner's book was also commented upon by the sociologist Angelika Ebbinghaus in 1999. Zeitschrift für Sozialgeschichte des 20 und 21. Jahrhunderts, where she pointed out that the documented fragments of Clara's life

could have provided the basis for a novel. Such a novel could have rendered the historical truth without necessarily being literally true. A biography, however, must fulfill other criteria, namely whether reality at least resembled that what has been presented.

Although von Leitner chose the scholarly genre of biography rather than novelshe ditched the standards of scholarship in the process of writing her account, such as documenting her statements by critically evaluated references. In her account she often puts statements/opinions in the heroine's mouth or describes situations involving the characters of her book for which no record or evidence exist. For instance, she states that "Clara admired the courageous Bertha von Suttner" and even describes a scene in which Clara discusses women's rights with her husband and takes the side of von Suttner. A partial list of statements and quotations appearing in von Leitner's and other accounts of Clara Haber's relation to chemical warfare that are of unknown origin have been listed elsewhere (Friedrich and Hoffmann 2016). 
Since neither Clara nor Fritz Haber left behind diaries or correspondence from which such opinions, conversations or situations could be reconstructed, these and other passages in von Leitner's book can only be regarded as an unscholarly mixture of fiction and historical fact. Of particular significance is von Leitner's contextualization of Clara's suicide, as this is presented as a decisive protest against the development and use of chemical weapons, as a signal "against the chemical mass destruction" (Leitner 1993) and as (Kokula 1988). ${ }^{15}$

a signal for a new definition of natural sciences that had not been heard.

The evidence provided by historical sources is too thin for such a strong hypothesis, not to speak about von Leitner's handling of the historical record. Therefore, we cannot but agree with an earlier assessment by Szöllösi-Janze that:

As regards the viability and validity of the sources, the record about the last months of

Clara Immerwahr's life during the First World War consists chiefly of gaps rather than proven knowledge (Szöllösi-Janze 1998, 395).

Despite all these defects and their explicit critique in the press as well as in Szöllösi-Janze's authoritative Haber biography, the image of Clara Haber, nee Immerwahr as an outspoken pacifist and opponent of chemical warfare prevails in the public awareness until this day.

Herein, we plead for a more differentiated view based on the available historical record, according to which Clara Haber's suicide appears to have likely been the result of a "catastrophic failure" (to borrow an engineering term as a metaphor) brought about by a most unfortunate confluence of a host of circumstances that included, apart from her unfulfilling life, Haber's philandering, the tragic deaths of her close friends, Richard Abegg and Otto Sackur, as well as the death and destruction of the war itself, amplified by the perversions of chemical warfare.

\section{$7 \quad$ Epilog}

Our intention has been to make the above points without belittling in the least Clara's achievements and courage. Honoring Clara, for instance through the Clara Immerwahr Award of the Nobel-Prize winning organization International Physicians for the Prevention of Nuclear War (IPPNW) or the Clara Immerwahr Prize of the Berlin Excellence Cluster UniCat, is highly to the point and should not be questioned in any way. Haber's institute, named after its founding director in 1952 and incorporated into the Max Planck Society in 1953, had a memorial built for Clara in the garden of the institute in 2006 (Fig. 3).

However, we should refrain from projecting our contemporary ideas about women's rights activists or peace activists on Clara Haber in an ahistorical way.

\footnotetext{
${ }^{15}$ Kokula is the maiden name of Gerit von Leitner.
} 

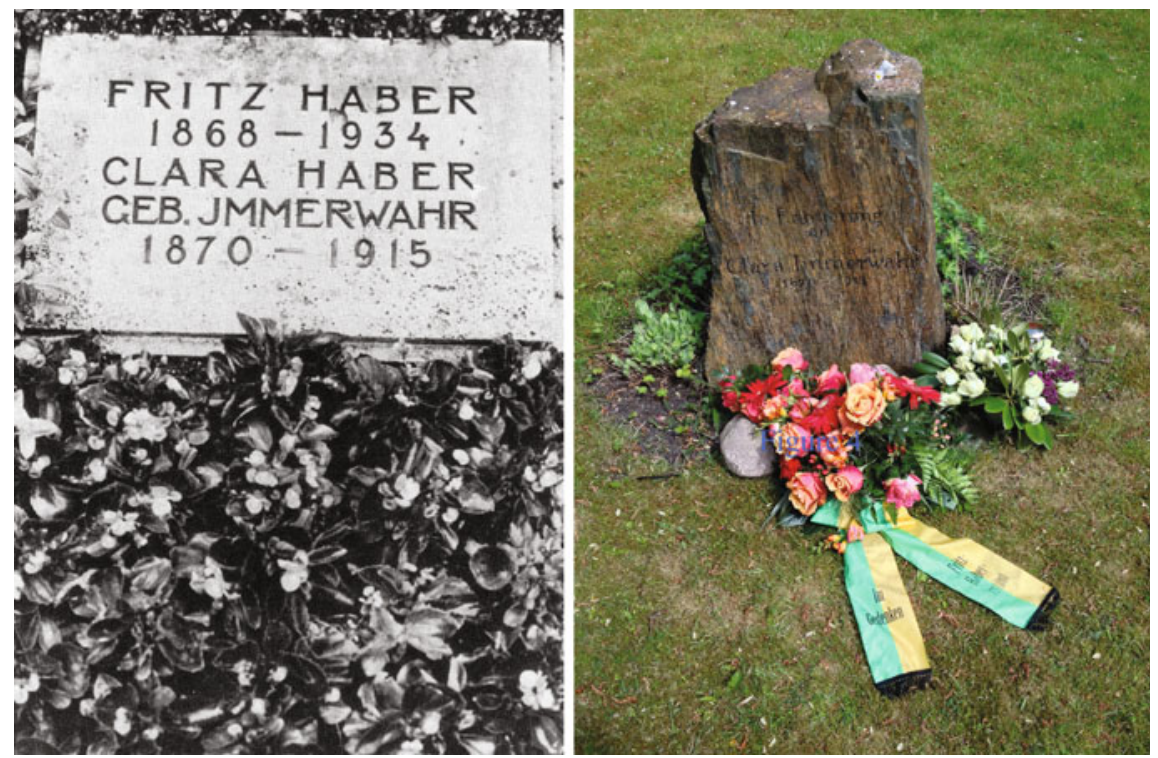

Fig. 3 Left panel Gravestone of Fritz and Clara Haber at the Hörnli Cemetery in Basel. In his testament, Haber expressed his wish to be buried alongside his first wife Clara - in Dahlem if possible, or elsewhere "if impossible or disagreeable." Haber's son Hermann became the will's executor. In accordance with this will, Clara's ashes were reburied beside Fritz Haber's in Basel. Photo: Archiv der Max-Planck-Gesellschaft, Berlin-Dahlem. Right panel Memorial for Clara Haber in the garden of the Fritz Haber Institute, installed in 2006. The photo by one of the authors (BF) shows the memorial at the centenary of Clara's suicide, on May 2, 2015

What she achieved in her time does not need to be embellished with exaggerations or even wishful thinking fashioned by present-day aspirations. Her achievements speak for themselves and should not be degraded or even compromised by mixing them up with fabrications and Wunschbilder.

Acknowledgements Our special thanks are due to Margit Szöllösi-Janze (Ludwig-Maximilians-Universität, München), whose authoritative biography Fritz Haber: 1868-1934 (C.H. Beck, München 1998) that covers both Fritz and Clara Haber proved to be an invaluable source of scholarship on the subject. In addition, Margit Szöllösi-Janze kindly provided comments specific to this article. We also thank Eckart Henning (former director of the Archive of the Max Planck Society, Berlin) for introducing us to the 1915 letters by Edith Hahn and Lise Meitner that mention Clara's suicide and that he has only recently published. We are also grateful to Hideki Tamaru Oyama (Rikkyo University) for making available to us the letter by her grandfather Setsuro Tamaru to Clara from December 24, 1914. Last but not least, we thank Gerhard Ertl (Fritz Haber Institute), Hajo Freund (Fritz Haber Institute), and Matthew Meselson (Harvard University) for a critical reading of the manuscript. 


\section{References}

Abegg, Richard, and Guido Bodländer. 1899. Die Elektroaffinität, ein neues Prinzip der chemischen Systematik. Zeitschrift für Anorganische Chemie 20: 453-499.

Arrhenius, Svante. 1910. Richard Abegg. Zeitschrift für Elektrochemie 16: 554-557.

Badino, Massimliano, and Bretislav Friedrich. 2013. Much polyphony but little harmony: Otto Sackur's groping for a quantum theory of gases. Physics in Perspective 15: 295-319.

Clark, Christopher. 2007. Iron kingdom: The rise and downfall of Prussia, 1600-1947. London: Penguin.

Davies, Norman, and Roger Moorhouse. 2002. Die Blume Europas. Breslau, Wroclaw, Vratislav. München: Droemer.

Dunikowska, Magda, and Ludwik Turko. 2011. Fritz Haber: The damned scientist. Angewandte Chemie Int Ed 50: 10050-10062.

Ebbinghaus, Angelika. 1993. 1999. Zeitschrift für Sozialgeschichte des 20 und 21. Jahrhunderts, Heft 4, 125-131.

Fischer, Ernst Peter. 1993a. Frau, Wissenschaftlerin, Pazifistin-und nach 80 Jahren noch unverstanden. Die Weltwoche, 19 August 1993, p. 23.

Fischer, Ernst Peter. 1993b. Professor Dr. Fritz. Die Tageszeitung (taz) v. 21.6.1993, S. 15.

Franck, James 1958. Note about Jaenicke's conversation with James Franck on 16-17 April 1958. Archiv der Max-Planck-Gesellschaft, Haber-Sammlung Va Abt., Rep. 5., Nr. 1449.

Friedrich, Bretislav. 2016. How did the tree of knowledge get its blossom? The rise of physical and theoretical chemistry, with an eye on Berlin and Leipzig. Angewandte Chemie Int Ed 55: 53785392.

Friedrich, Bretislav, and Dieter Hoffmann. 2016. Clara Haber, nee Immerwahr (1870-1915): Life, Work, and Legacy. Zeitschrift für anorganische und allgemeine Chemie 642: 437-448.

Goethe, Johann Wolfgang. 1949. Goethe, the story of a man: Being the life of Johann Wolfgang Goethe as told in his own words and the words of his contemporaries, vol. 1. New York: Farrar, Straus.

Goran, Morris. 1947. The present-day significance of Fritz Haber. American Scientist 35: 400403.

Goran, Morris. 1967. The story of Fritz Haber. Norman: University of Oklahoma Press.

Haber, Charlotte. 1970. Mein Leben mit Fritz Haber. Düsseldorf: Econ-Verlag.

Haber, Clara. 1901. Clara Haber to Richard Abegg, 18 October 1901. Archiv der Max-Planck-Gesellschaft, Haber Sammlung Va Abt., Rep. 5., Nr. 812.

Haber, Clara. 1909. Clara Haber to Richard Abegg, 23 April 1909. Haber Collection. Archiv der Max-Planck-Gesellschaft, Haber-Sammlung Va Abt., Rep. 5., Nr. 812.

Haber, Clara. 1915. Clara Haber to Setsuro Tamaru, 15 January 1915. Oyama, Hideko. 2015. Setsuro Tamaru and Fritz Haber: Links between Japan and Germany in Science and Technology, Chemical Record 15: 535-549.

Haber, Fritz. 1901. Fritz Haber to Professor [unknown], 18 April 1901. Archiv der Max-Planck-Gesellschaft, Haber-Sammlung Va Abt., Rep. 5., Nr. 1874.

Haber, Fritz. 1908. Thermodynamics of technical gas-reactions. London: Longmans, Green \& Co.

Haber, Fritz. 1920. Die chemische Industrie 43: 350-352.

Haber, Fritz. 1924. Fünf Vorträge aus den Jahren 1920-1923. Berlin: Springer.

Hahn, Edith. 1915. Edith Hahn to Otto Hahn, 5 May 1915. Archiv der Max-Planck-Gesellschaft, Va. Abt., Rep 55, Hahn-Sammlung, Nr. 96.

Hahn, Ralf. 1999. Gold aus dem Meer. Die Forschungen des Nobelpreisträgers Fritz. Haber in den Jahren 1922-1927. Berlin, Diepholz: GNT.

Henning, Eckart. 1990. Die Haber-Sammlung im Archiv zur Geschichte der Max-Planck-Gesellschaft. Berichte zur Wissenschaftsgeschichte 13: 34-37.

Henning, Eckart. 2016. Freitod in Dahlem (1915): Unveröffentlichte Briefe von Edith Hahn und Lise Meitner über Dr. Clara Haber geb Immerwahr. Zeitschrift für anorganische und allgemeine Chemie 642: 432-436. 
Immerwahr, Clara. 1900a. Potentiale von Kupferelektroden in Lösungen analytisch wichtiger Kupferniederschläge. Zeitschrift für Anorganische Chemie 24: 269-278.

Immerwahr, Clara. 1900b. Berichtigung zu meiner Arbeit 'Potentiale von Kupferelektroden in Lösungen analytisch wichtiger Kupferniederschläge'. Zeitschrift für Anorganische Chemie 24: 112.

Immerwahr, Clara. 1901a. Beiträge zur Kenntnis der Löslichkeit von Schwermetallniederschlägen auf elektrochemichem Wege. Zeitschrift für Elektrochemie 7: 477-483.

Immerwahr, Clara. 1901b. Berichtigung. Zeitschrift für Elektrochemie 7: 625.

Immerwahr, Clara, and Richard Abegg. 1900. Notiz über das Elektrochemische Verhalten des Fluorsilbers und des Fluors. Zeitschrift für Physikalische Chemie, Stochiometrie und Verwandtschaftslehre 32: 142-144.

Jaenicke, Johannes. 1958. J. Jaenicke to H. Lütge, Berlin 6 January 1958. Archiv der Max-Planck-Gesellschaft, Haber-Sammlung Va Abt., Rep. 5., Nr. 260.

James, Jeremiah, Thomas Steinhauser, Dieter Hoffmann, and Bretislav Friedrich. 2011. One Hundred Years at the Intersection of Chemistry and Physics. The Fritz Haber Institute of the Max Planck Society 1911-2011. Berlin: De Gruyter.

Johnson, Jeffrey. 1998. German women in chemistry, 1895-1925 (Part I). NTM Zeitschrift für Geschichte der Wissenschaften, Technik und Medizin 6: 1-21.

Kokula, Gerit. 1988. Gegen die Perversion. Vom verlorenem Kampf der Chemikerin Clara Immerwahr. Tagesspiegel v. 29.12.1991, p. IV (Supplement).

Krassa, Hans. 1957. Hans Krassa to Johannes Jaenicke, 2 November 1957, Archiv der Max-Planck-Gesellschaft, Haber-Sammlung Va Abt., Rep. 5., Nr. 1470.

Kremmer, [first name unknown]. 1934. Dr. Kremmer to Hermann Haber, 2 February 1934. Archiv der Max-Planck-Gesellschaft, Haber-Sammlung Va Abt., Rep. 5., Nr. 1222.

Leitner, von Gerit. 1993. Der Fall Clara Immerwahr. Leben für eine humane Wissenschaft, München: C.H. Beck.

Lummitzsch, Otto. 1955. Erinnerungen. Archiv der Max-Planck-Gesellschaft, Haber-Sammlung Va Abt., Rep. 5., Nr. 1480.

Lütge, Hermann. 1958. Hermann Lütge to Johannes Jaenicke, 9 and 17 January 1958, Archiv der Max-Planck-Gesellschaft, Haber-Sammlung Va Abt., Rep. 5., Nr. 260.

Meitner, Lise. 1915. Lise Meitner to Edith Hahn, 6 May 1915. Archiv der Max-Planck-Gesellschaft, Va. At, Rep. 55, Hahn-Sammlung, Nr. 94.

Mendelssohn, Kurt. 1973. The world of Walther Nernst. The rise and fall of German Science. London: MacMillan.

Nernst, Walther. 1913. Richard Abegg. Chemische Berichte 46: 619-628.

Noack, Adelheid. 1959. Recollection from 19 November 1959. Archiv der Max-Planck-Gesellschaft, Haber-Sammlung Va Abt., Rep. 5., Nr. 301.

Ostwald, Wilhelm. 1887. An die Leser. Zeitschrift für Physikalische Chemie 1: 1-4.

Perutz, M.F. 1996. The Cabinet of Dr. Haber. New York Review of Books, 20.6.1996, p. 31-36.

Planck, Max 1897. Die Akademische Frau. Gutachten hervorragender Universitätsprofessoren, Frauenlehrer und Schriftsteller über die Befähigung der Frau zum wissenschaftlichen Studium und Berufe, edited by Artur Kirchhoff, Berlin: Hugo Steinitz Verlag.

Scheuermann, Gerhard. 1994. Das Breslauer Lexikon. Dülmen: Laumann-Verlag.

Stern, Fritz. 2011. Fritz Haber: Flawed greatness of person and country. Angewandte Chemie International Edition 51: 50-56.

Stoltzenberg, Dietrich. 2004. Fritz Haber. Chemist, Nobel Laureate, German, Jew. Philadelphia: Chemical Heritage Press (in German already 1994, Weinheim: VCH).

Szöllösi-Janze, Margit. 1998. Fritz Haber 1868-1934. Eine Biographie. München: C.H. Beck.

Tamaru, Setsuro. 1914. Setsuro Tamaru to Clara Haber, 24 December 1914. Private collection of Hideko Tamaru Oyama: Rikkyo University, Tokyo.

Ullrich, Volker. 1993. Volker Ullrich. Die Zerstörung einer Frau, Die Zeit 4 (6): 1993.

Van Rahden, Til. 2008. Jews and Other Germans: Civil Society, Religious Diversity, and Urban Politics in Breslau 1860-1925. University of Wisconsin Press.

Vogel, Jakob. 1993. Die geistige Amazone. Frankfurter Allgemeine Zeitung 14 (9): 1993. 


\section{Addition to Open Access Information}

Sections 2-7 reproduced with permission from Wiley-VCH Verlag GmbH \& Co. $\mathrm{KGaA}$. This material has been material published in Friedrich, Bretislav and Dieter Hoffmann, Zeitschrift für anorganische und allgemeine Chemie (2016) 642: 437448. (C) The Authors. Published by Wiley-VCH Verlag GmbH \& Co. KGaA, Weinheim as an open access article under the terms of the Creative Commons Attribution-NonCommercial-NoDerivs License, which permits use and distribution in any medium, provided the original work is properly cited, the use is non-commercial and no modifications or adaptations are made. Further permissions for Sects. 2-7 must be directly obtained from Wiley-VCH Verlag $\mathrm{GmbH} \& \mathrm{Co}$. KGaA.

Open Access This chapter is licensed under the terms of the Creative Commons Attribution-NonCommercial 2.5 International License (http://creativecommons.org/licenses/by-nc/ $2.5 /)$, which permits any noncommercial use, sharing, adaptation, distribution and reproduction in any medium or format, as long as you give appropriate credit to the original author(s) and the source, provide a link to the Creative Commons license and indicate if changes were made.

The images or other third party material in this chapter are included in the chapter's Creative Commons license, unless indicated otherwise in a credit line to the material. If material is not included in the chapter's Creative Commons license and your intended use is not permitted by statutory regulation or exceeds the permitted use, you will need to obtain permission directly from the copyright holder.

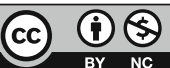

